\title{
REPLY TO REVIEW IN “HEMODYNAMIC RESPONSE AFTER CONCURRENT CROSS EXERCISE IN HYPERTENSIVE WOMEN"
}

\author{
RESPOSTA PARA A REVISÃO SOBRE "RESPOSTAS HEMODINÂMICAS PÓS-EXERCÍCIO CONCORRENTE \\ CRUZADO EM MULHERES HIPERTENSAS"
}

ANSWER LETTER

CARTA RESPOSTA

CARTA RESPOSTA

\section{RESPUESTA A LA REVISIÓN SOBRE "RESPUESTAS HEMODINÁMICAS POSTEJERCICIO CONCURRENTE CRUZADO EN MUJERES HIPERTENSAS"}

Erik de Cerqueira Wanderley' (ID (Physical Education Professional) Alice Conrado de Souza' (ID (Physical Education Professional) Laiza Ellen Santana Santos ${ }^{1}$ (ID (Physical Education Professional)

Alexandra de França Pacheco' (ID (Physiotherapist)

Pedro Danilo Paiva Costa' (ID (Physical Education Professional) Roberto Emmanuel Nascimento Santos ${ }^{1}$ (ID)

(Physical Education Professional)

Lucas Santos Novais' ${ }^{1}$ (D) (Physical Education Professional)

Rogerio Brandão Wichi ${ }^{2}$ (ID

(Physical Education Professional)

Emerson Pardono ${ }^{2}$ (D)

(Physical Education Professional)

1. Universidade Federal de Sergipe (UFS); Postgraduate Program in Physical Education, Sergipe,

SE, Brazil.

2. Universidade Federal de Sergipe (UFS), Department of Physical Education, Postgraduate Program in Physical Education, Sergipe, SE, Brazil.

\section{Correspondence:}

Erik de Cerqueira Wanderley. Rua Matilde Silva Lima: № 550. Cond Andaluzia, Bl Cordoba, Apto. 504. Bairro. Luzia. Cidade Aracaju e Estado Sergipe. Brazil. 49045-083. erikzero8@hotmail.com
We appreciate the considerations of Review In "Hemodynamic Response After Concurrent Cross Exercise In Hypertensive Women "by Letieri at al. In answer, we point out:

1. The objective of the present study was not to verify the concurrent effect, but to verify hypotensive effect and pressure reactivity after concurrent exercise crossed. The literature already has countless published works that study the isolated effects of aerobic exercise and resistance exercise. Thus we focus on the joint effect. In addition, the study verified the presence acute effect after exercise and not chronic effect resulting from physical training, in which the sample performed the exercise session and the control session.

2. The $8 \mathrm{RM}$ protocol is a protocol with internal and external validity and reliability, therefore, the exercise prescription met the intensity of $75 \%$ of 8 RM, used by Azevêdo et al., 2017.'

3. The intense term the treatment we gave to level 14 , which is transitional and non-intermediate and that can be consulted in scale with ratio properties the Borg, 1982.' In addition, it was the protocol adopted for prescription of intensity in aerobic exercise. As is indicated by the literature, people with arterial hypertension and medicated with beta-blockers have controlled heart rate rhythm demonstrated by Gascón et al., 1988,3 therefore, to measure it without considering other parameters such as blood pressure can result in bias. We further affirm that in our methodological procedure we do not measure the cardiac frequency during aerobic exercise, we measure together with blood pressure at end of the concurrent exercise session.

\section{All authors declare no potential conflict of interest related to this article}

AUTHORS' CONTRIBUTIONS: ECW: writing, intervention, statistical analysis, intellectual concept and preparation of the whole study; ACS: intervention, data analysis, and writing; LESS: data analysis, and writing; AFP, PDPC, RENS, and LSN: writing and revision; RBW: intellectual concept, revision; EP: intellectual concept, statistical analysis, writing, and revision. All the authors revised and approved the final version of the manuscript.

\section{REFERENCES}

1. Azevedo LM, Souza AC, Santos LES, Santos RM, Fernandes MOM, Almeida JA, Pardono E. Fractionated Concurrent Exercise throughout the Day Does Not Promote Acute Blood Pressure Benefits in Hypertensive Middle-aged Women. Frontiers in cardiovascular Medicine. 2017; 4(6):
2. Borg GAV. Psychophysical bases of perceived exertion. Medicine \& Science in Sports \& Exercise. 1982; 14(5)377-81.

3. Gascón JVG, Ros JO, Reig JF, Martinez MH, Siscar PB, Catala GE, Vidal FJ. Exercise Stress test in Young Hypertensive Patients. Response to Vasodilators (Prazosin) vs. Beta-Blocker (Atenolol) Agents. Clin Cardiol. 1988; 11(1): 24-34 